\title{
Population expansion of a new invasive coral species, Tubastraea micranthus, in the northern Gulf of Mexico
}

\author{
Paul W. Sammarco ${ }^{1,2, *}$, Scott A. Porter ${ }^{1,3}$, James Sinclair ${ }^{4}$, Melissa Genazzio ${ }^{1,5}$ \\ ${ }^{1}$ Louisiana Universities Marine Consortium (LUMCON), 8124 Hwy. 56, Chauvin, Louisiana 70344, USA \\ ${ }^{2}$ Department of Oceanography and Coastal Sciences, Louisiana State University, Baton Rouge, Louisiana 70803, USA \\ ${ }^{3}$ Ecologic Environmental, PO 886, Houma, Louisiana 70361, USA \\ ${ }^{4}$ US Department of the Interior, Bureau of Safety and Environmental Enforcement, 1201 Elmwood Park Blvd., New Orleans, \\ Louisiana 70123-2394, USA \\ ${ }^{5}$ Center for Marine Science, University of North Carolina at Wilmington, 601 S. College Rd., Wilmington, \\ North Carolina 28403-5928, USA
}

\begin{abstract}
An Indo-Pacific scleractinian coral has invaded the northern Gulf of Mexico (GOM): Tubastraea micranthus. It was initially observed on one oil platform (GI-93C) near the Mississippi River. Here, we determined whether its populations were spreading and whether there was evidence of rapid expansion. We compared population density data of T. micranthus with those from T. coccinea, a congener which invaded the western Atlantic earlier. Fourteen oil/gas platforms were assessed down to $138 \mathrm{~m}$ depth using remotely operated vehicle digital video. Colony densities in numbers $\mathrm{m}^{-2}$ were determined for both species, and colony size was measured for T. micranthus. Data were analyzed by platform and for geographic distribution. T. micranthus densities were highest on GI-93C and on GI-116A, SW of the Mississippi River, being significantly higher than on other platforms. Densities declined radially from there. Mean colony size was highest on MC-311A, with colonies generally being $>100 \mathrm{~cm}^{2}$. This platform is situated at the head of the Mississippi Canyon and may have been the original site of colonization. It also receives blue water instead of turbid, lower salinity water, and this species may grow better under those conditions. T. micranthus size frequency distributions were generally skewed towards $1-200 \mathrm{~cm}^{2}(5 \mathrm{~cm}$ diameter) (sometimes $>90 \%$ of the population), suggesting that most populations are potentially in an expanding growth phase. T. coccinea densities were high (range: $\sim 50$ to 300 colonies $\mathrm{m}^{-2}$ ). Its populations were also centered SW of the Mississippi River. T. micranthus is spreading through this region, and the window for its potential eradication may be closing.
\end{abstract}

KEY WORDS: Coral - Invasive species - Tubastraea micranthus - Gulf of Mexico - Spread . Oil platforms

\section{INTRODUCTION}

Species introductions can result in major impacts on ecosystems (Roberts \& Pullin 2008). This is particularly so in the marine environment because of the ease with which reproductive propagules can dis- perse and colonize nearby habitats once they have established a new population (Griffiths 1991, Johnson \& Carlton 1996, Wonham et al. 2000). Examples of rapid dispersal of introduced marine species are numerous and include marine algae (Chapman et al. 2006), such as Codium fragile, a Japanese chloro- 
phyte introduced apparently via the ballast water of ships (Trowbridge 1998, Pederson 2000, Williams 2007). This species is now common throughout much of the western Atlantic (Chapman 1999). Another example is Caulerpa taxifolia, which was accidentally released into the Mediterranean Sea from a public aquarium in Monaco (Williams \& Smith 2007) and is now common there. Another more recent example is the Indo-Pacific volitan lionfish Pterois volitans. This species was most likely released into western Atlantic waters $~ 10 \mathrm{yr}$ ago (Whitfield et al. 2002, Hamner et al. 2007) and is now distributed from New York, USA, south through the Caribbean and South America (Albins \& Hixon 2011). There are hundreds to thousands of such examples of introductions from various seas, which are reviewed by e.g. Bax et al. (2003), Womersley (2003; Australian algae), Zenetos et al. (2005; Mediterranean fauna).

Vectors for the transport of invasive marine or freshwater species (Kerr et al. 2005) include the ballast water of barges or ships (Chesapeake Bay Commission 1995, ICES 2002), the hulls of the same (Minchin \& Gollasch 2003), transfer via towing of oil and gas platforms to new sites (Hicks \& Tunnell 1993), accidental release of exotic species from mariculture operations (Sapota 2004), and deliberate release of exotics by aquarium hobbyists (Weidema 2000, Christmas et al. 2001, Hindar et al. 2006). Recent concern regarding invasive marine species has focused on those in the Gulf of Mexico (GOM) (Osman \& Shirley 2007). This includes the Australian scyphozoan Phyllorhiza, which colonized this region within the past $15 \mathrm{yr}$ (Perry \& Graham 2000) and has the ability to suppress seasonal zooplankton populations (Graham et al. 2003, Graham \& Bayha 2008) important for commercial fisheries.

Very few corals have successfully invaded the Atlantic. The Indo-Pacific mushroom coral Fungia scutaria was accidentally introduced into Discovery Bay, Jamaica, West Indies (Lajeunesse et al. 2005, J. Lang pers. comm., P. W. Sammarco pers. obs. 1973). (The corals were held in running seawater tables for several years, and it is hypothesized that, during the spawning seasons, planulae were released into the water and flushed into the lagoon through the seawater discharge drain.) The IndoPacific sun coral Tubastraea coccinea (Cairns \& Zibrowius 1997) was introduced into Puerto Rico in 1943 and by 1948 had spread to Curacao, Netherlands Antilles (Cairns 2000). By the late 1990s and mid 2000s, this species had spread to Belize and Mexico (Fenner 1999); Venezuela, northern GOM, and the Florida Keys (Fenner 2001, Fenner \& Banks
2004, Sammarco et al. 2004, Shearer 2008); Brazil (Figueira de Paula \& Creed 2004); Colombia, Pana$\mathrm{ma}$, the Bahamas, and throughout the Lesser and Greater Antilles (Cairns 2000, Humann \& Deloach 2002). This species is now abundant in the northern GOM on artificial substrata (Sammarco et al. 2004, $2007 a, b, 2012 a)$. It is present on oil/gas platforms in abundances of hundreds of thousands of colonies per platform, with average densities of 28 to 300 colonies $\mathrm{m}^{-2}$. It also occurs on natural carbonate banks in the northern GOM, but in lower abundances (Schmahl 2003, Hickerson et al. 2006, Schmahl \& Hickerson 2006). It is possible that this introduction was due to a ship, barge, or ballast water, although the details are not known. It is also possible that oil and gas platforms, abundant in the northern GOM, have acted as stepping stones for the geographic expansion of this species in this region (Sammarco et al. 2004, Atchison 2005, Atchison et al. 2008, Sammarco et al. 2012a,b). It should be noted, however, that such a geographic spread was achieved throughout most of the western Atlantic without these structures; that is, such structures were sufficient but not necessary for the spread of this species.

From 2000 to 2010, Sammarco et al. (2004, 2007a,b, 2008, 2012a) and S. A. Porter (unpubl. data) conducted surveys via SCUBA and remotely operated vehicle (ROV) on the distribution and abundance of scleractinian corals on 81 oil and gas platforms in both shallow and deep water throughout the northern GOM. Surveys were conducted in offshore waters spanning Corpus Christi, TX, to Mobile, AL. In his surveys, S. A. Porter found a new invasive species for the GOM: the Indo-Pacific black sun coral Tubastraea micranthus Cairns \& Zibrowius 1997 (Sammarco et al. 2010), a closely related congener of T. coccinea. It was initially observed in 2006 on a single platform: GI-93-C $\left(28^{\circ} 32.96^{\prime} \mathrm{N}, 90^{\circ} 40.11^{\prime} \mathrm{W}\right.$; Fig. 1). This was near the crossing of 2 major safety fairways/shipping channels southwest of the Port of New Orleans, LA, near the mouth of the Mississippi River and Port Fourchon, LA. Once a population of a new invasive species becomes established, its spread can be broad and rapid, greatly confounding any attempt to control or eradicate it (Elton 2000).

An understanding of Tubastraea coccinea's life history traits will assist in understanding some of the potential that $T$. micranthus has for geographic expansion in the GOM and allow comparisons between the 2 species. T. coccinea generally has colony sizes no larger than $25 \mathrm{~cm}$ in diameter in the GOM, at which point it extends runners horizontally to form new ramets. Its growth form in the Atlantic is branching 


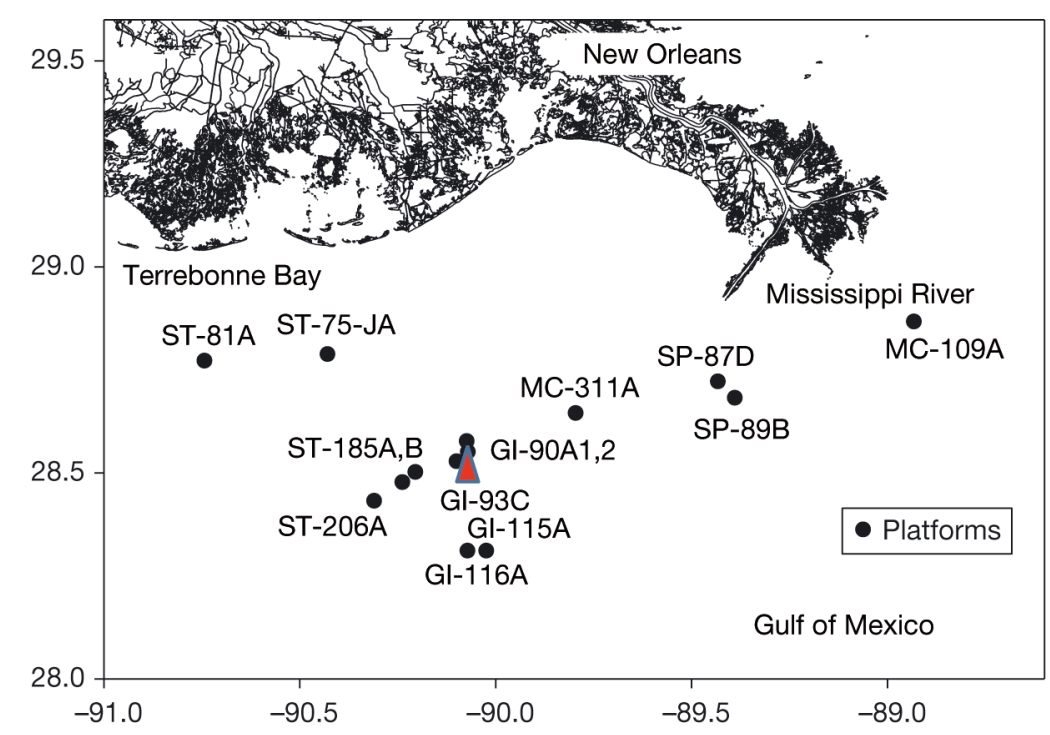

Fig. 1. Map of the north-central Gulf of Mexico (GOM) showing locations of the 14 offshore oil and gas platforms studied. (A) Platform GI-93-C, where Tubastraea micranthus was first sighted (Sammarco et al. 2010)

runner production (Pagad 2007). It is considered to be a highly fecund species and produces gametes all year-round, even in the smallest colonies (2 to 10 polyps; Glynn et al. 2008a,b). The planular development period is $6 \mathrm{wk}$, and the planulae settle and metamorphose within $3 \mathrm{~d}$. Planular release occurs 3 to 4 times per year (Hebbinghaus 2001) from March through July, and this species is considered to possess substantial larval dispersal capabilities (Sammarco et al. 2012b). It is known to withstand a variety of environmental conditions that cause bleaching and mortality in other coral species.

With respect to Tubastraea micranthus, the details of its reproduction, dispersal capabilities, time from release to settlement for planulae, and any obligate period that the planulae must remain in

but with a low profile, to a maximum of 12 to $15 \mathrm{~cm}$. The polyps are red or orange in color, and the corals are ahermatypic and azooxanthellate. Their natural habitat on Indo-Pacific reefs is cryptic, and this same habitat is adopted on natural reefs in the western Atlantic. On artificial substrata, however, the colonies are much more exposed. With respect to T. micranthus, colony sizes are somewhat smaller $(15 \mathrm{~cm}$ in diameter) in the GOM. The colonies also distribute runners to form new ramets. It is also branching in habit, but its polyps extend to a greater extent vertically and branch as well, making the colonies often a bit taller (up to $\sim 20 \mathrm{~cm}$ high; Cairns 2000 , Sammarco et al. 2010). They are dark green or black in color and are also ahermatypic and azooxanthellate. Their natural habitat on Indo-Pacific reefs is exposed. It is not yet known what their habit will be on natural reefs in the GOM, although they are generally exposed on oil and gas platforms there. The ability of T. micranthus to grow well in highly exposed habitats is reason for concern since preliminary data indicate that this species has a strong advantage in competition for space against other sessile, benthic epifauna (Sammarco et al. 2012a,b).

Regarding reproduction, Tubastraea coccinea is a single species with a circum-tropical distribution (Cairns 2001). It is a hermaphroditic brooder and reproduces by producing planulae year-round (Glynn et al. 2008a). Egg development requires 6 to $8 \mathrm{wk}$. $T$. coccinea exhibits asexual reproduction using budding, simple colony growth, and asexual planula production (Ayre \& Resing 1986, Shearer 2008) and the water column prior to settlement are not yet known. If they are similar to those of $T$. coccinea, then T. micranthus could reach abundances similar to its congener in the western Atlantic (Sammarco et al. 2004, Shearer 2008). As such, this species could pose a potential threat via substantial geographic expansion throughout the GOM and the tropical and sub-tropical western Atlantic over the next 20 to 40 yr.

The objectives of the present study were to quantify the abundance of Tubastraea micranthus at the initial site of observation (Platform GI-93-C, see above) and to conduct surveys on 13 other platforms in the vicinity of GI-93-C, extending to the bottom, to determine whether its populations are expanding. We also assessed the direction in which the expansion is occurring, in what types of environments it occurs, and to what degree. Depth distribution information and competition-for-space capabilities of this species will be considered elsewhere (Sammarco et al. in press b).

\section{MATERIALS AND METHODS}

\section{Study site}

The study sites were Platform GI-93-C and 13 other platforms surrounding it within a $20 \mathrm{~km}$ radius (Fig. 1, Table 1). Specific platforms were chosen in consultation with the US Department of the Interior Bureau of Ocean Energy Management (BOEM). 
Table 1. List of 14 platforms in the northern Gulf of Mexico (GOM), near the mouth of the Mississippi River, video-surveyed by ROV for the ahermatypic invasive Indo-Pacific corals Tubastraea micranthus and T. coccinea. Platform number, name, owner, latitude and longitude of geographic location, and number of quadrats analyzed per platform are provided

\begin{tabular}{|c|c|c|c|c|c|}
\hline $\begin{array}{l}\mathrm{Pl}_{\text {Number }} \\
\text { N }\end{array}$ & $\begin{array}{l}\text { atform }- \\
\text { Code }\end{array}$ & Owner & Latitude & Longitude & $\begin{array}{c}\text { Number of } \\
\text { quadrats }\end{array}$ \\
\hline 1 & GI-90A-1 & Apache Corp. & 28.575144 & -90.072429 & 23 \\
\hline 2 & GI-90A-2 & Apache Corp. & 28.575144 & -90.072429 & 129 \\
\hline 3 & GI-93C & Apache Corp. & 28.548886 & -90.068677 & 125 \\
\hline 4 & GI-115A & Walter Oil \& Gas Corporation & 28.3076123 & -90.0219665 & 44 \\
\hline 5 & GI-116A & Apache Corp. & 28.30928306 & -90.07054334 & 44 \\
\hline 6 & MC-109A & Stone Energy Corporation & 28.86467752 & -88.93079054 & 88 \\
\hline 7 & $\mathrm{MC}-311 \mathrm{~A}$ & Apache Corp. & 28.642636 & -89.794241 & 174 \\
\hline 8 & SP-87D & Apache Corp. & 28.72001853 & -89.43078669 & 79 \\
\hline 9 & SP-89B & Apache Corp. & 28.680464 & -89.387596 & 90 \\
\hline 10 & ST-75-JA(B) & Stone Energy Corporation & 28.76955709 & -90.74085664 & 12 \\
\hline 11 & ST-81A & Stone Energy Corporation & 28.78656092 & -90.42747823 & 18 \\
\hline 12 & ST-185A & Black Elk Energy Offshore Operations, LLC & 28.495501 & -90.203098 & 87 \\
\hline 13 & ST-185B & Black Elk Energy Offshore Operations, LLC & 28.47493 & -90.235942 & 22 \\
\hline 14 & ST-206A & Apache Corp. & 28.45372522 & -90.38341283 & 50 \\
\hline
\end{tabular}

Choices were based on age and location of the structures and availability with respect to the platform owners. Surveys were performed using the M/V 'Fling' (33 m, Gulf Diving, Freeport, TX) and the R/V 'Acadiana' (18 m, LUMCON). The study was conducted over $2 \mathrm{yr}$, utilizing $12 \mathrm{~d}$ of ship-time. Twothirds of a day were required to survey each platform using an ROV.

We used LUMCON's Deep Ocean Engineering Phantom S2 ROV, which has $333 \mathrm{~m}$ of umbilical and is capable of surveying down to $170 \mathrm{~m}$ depth. We employed techniques previously used successfully in earlier similar surveys (Sammarco et al. 2010, 2012a). ARACAR's SeaBotix LBV-300 and BOEM's similar ROV were also used as back-ups. All units were fitted with vertical and horizontal propulsion units, siteto-surface color video units, a topside monitor, lights, laser beams providing a spatial scale reference, and a sample retrieval unit (fixed grab). The length of transects varied between $18 \mathrm{~m}$ for horizontal struts and $170 \mathrm{~m}$ for the deepest vertical piling. The number of transects varied between 4 and 7 per platform, depending upon the size of the platform. Transects consisted of 2 to 6 horizontal transects at approximately $15-18,23-27$, and $\sim 180 \mathrm{~m}$ depth; the remainder of the transects were vertical. Approximately 125 to $585 \mathrm{~m}^{2}$ of substratum were surveyed on each platform, depending upon the size of the platform (number of primary pilings), depth, time available at each platform, and weather and sea conditions. We filmed continuously down each leg and only on the outward-facing surfaces. The side of the platform sampled was always down-current to ensure that the ROV and/or its umbilical was not drawn into the interior of the structure, to reduce the probability of it becoming fouled (see Sammarco et al. in press).

Imagery was processed using Dell Precision 340 and T3400 desktop computers with a Pentium 4 processor and a Dell Precision M4300 Workstation fitted with a duo-core processor and MicroSoft video imaging software. Image analysis software included Nero 7.0, VideoLAN, and MicroSoft Windows Media Player, capable of zoom and still-image capture. Images were analyzed at each $3 \mathrm{~m}$ interval within a video transect. Per platform, 12 to 174 quadrats were analyzed, depending upon platform size and depth (see Table 1).

Data were collected for both Tubastraea micranthus and T. coccinea for comparative purposes. In the case of $T$. coccinea, population densities were so high (up to hundreds per still image) that counts were estimated visually using a $\log _{5}$ code system $(0=1,1=5$, $2=25,3=125$, etc.), similar to that used in the field by Williams (1982) and Halford et al. (2004) for reef fish counts. Two laser dots of known inter-dot distance ( 8 to $12 \mathrm{~cm}$, depending upon the vehicle) within the video field of view were used to standardize for both coral density (no. corals per unit area) and coral colony size. A transparent $25.4 \times 25.4 \mathrm{~cm}$ grid comprised of 100 squares was placed over the computer screen to assist sampling and taking measurements. Mean densities of corals were calculated for each platform along with standard deviations and $95 \%$ confidence limits.

Colony size was measured for all Tubastraea micranthus colonies. Similar data are not presented for $T$. coccinea because $T$. micranthus was the target 
organism for the present study and the objective was to discern characteristics of initial population changes in the region. It is known that $T$. coccinea populations are well established in the region (Sammarco et al. 2012a). Colonies were assumed to be elliptical in shape, and measurements were made of the major and minor axes. Estimated area was calculated as $\mathrm{A}=\pi r_{1} r_{2}$, where $r_{1}$ and $r_{2}$ are the major and minor radii, respectively. Mean coral colony size was calculated for each platform along with standard deviations and $95 \%$ confidence limits. Sizefrequency diagrams were constructed for T. micranthus colonies on each of the platforms, based on all quadrats analyzed per platform.

\section{Data analysis}

All quantitative data were logged in Excel files and stored on the primary workstation. Data were backed-up on an external hard-drive and updated as well on the LUMCON computer network.

Coral density data were analyzed by parametric tests. Analyses included ANOVA and a posteriori multiple comparison tests between means: T-K, GT2 , and $\mathrm{T}^{\prime}$ tests. Basic statistics (mean, SD, n, range, $\mathrm{g}_{1}$ - skewness, and $\mathrm{g}_{2}$ - kurtosis) were calculated for colony size frequency distributions. Analyses were performed using BiomStat 3.2 and 3.3 (Rohlf \& Slice 1996). Where necessary, data were transformed by square root of $(Y+0.5)$ for normalization purposes (see Sokal \& Rohlf 1981).

Two-dimensional graphics were created using SigmaPlot 10.0. Some data are presented within a geographic context in 3 dimensions, and these were constructed using Surfer 8.0. Data consisted of latitudes, longitudes, and the variate in question. Averages were determined by kriging, a geostatistical gridding method designed for use with irregularly spaced data, using a smoothing interpolator. We used point kriging, estimating interpolated values of points at grid nodes, and a default linear variogram without a nugget effect. Additional details may be found in Golden Software (2002).

\section{RESULTS}

\section{Tubastraea micranthus}

Data derived from analysis of ROV videos revealed that Tubastraea micranthus populations were indeed distributed on other platforms besides GI-93-C in the study area. Of the 14 platforms surveyed, this species was found on 9, including GI-93-C (Fig. 2). However, density data was highest on this platform of initial sighting, averaging $\sim 15$ colonies $\mathrm{m}^{-2}$. This suggests that this site experienced substantial colonization from elsewhere. ANOVAs and subsequent a posteriori tests revealed that densities on GI-93C were significantly higher than on all other platforms except GI-116A (Table 2A), which was not significantly different than GI-93C. Details regarding inter-platform comparisons may be found in Table 2A. T. micranthus did not occur on Platforms ST-185A \& B, GI-94B, ST-81A, and ST-75JA(B) (Fig. 2).

The peak density of Tubastraea micranthus occurred to the southwest of the mouth of the Mississippi River (Fig. 3), next to 2 major safety fairways servicing the Port of New Orleans and Port Fourchon (Sammarco et al. 2010). A second somewhat smaller peak in density occurred south of GI-93-C. This suggests that the introduction of this species may have been derived from larvae being released from a passing ship or barge. In general, densities decreased in all directions in near proximity to these points, with a minor peak west-southwest of the Mississippi River mouth. Densities rose moderately to the east of the Mississippi River.

Patterns of average colony size for Tubastraea micranthus did not follow that of average density. Maximum average colony size was on Platform MC-311A

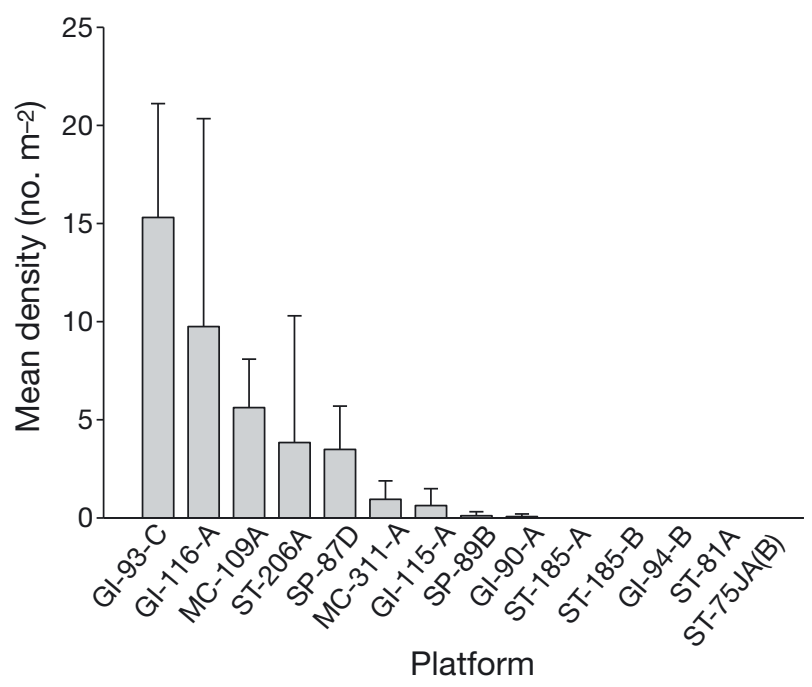

Fig. 2. Density of Tubastraea micranthus on 14 offshore oil/ gas platforms in the northern GOM. Densities shown in no. of colonies $\mathrm{m}^{-2}$ with $95 \%$ confidence limits. Densities are highly significantly different from each other $(\mathrm{p}<0.001,1-$ way ANOVA). Data transformed via square-root of $(Y+0.5)$ for purposes of normalization (see Sokal \& Rohlf 1981). See Table 2A for details of inter-platform comparisons. See Table 1 for sample sizes 
Table 2. Summary of results of a posteriori multiple comparisons of means tests performed on (A) mean colony densities and (B) mean colony sizes of Tubastraea micranthus, and (C) mean colony densities of T. coccinea on 14 oil/gas platforms in the northern GOM. In all cases, only significant rows are shown. T', T-K, and GT-2 tests were used. Results of pairwise comparisons shown. Platforms are shown in order of density, high to low. An asterisk denotes a significant difference between coral densities on 2 given platforms

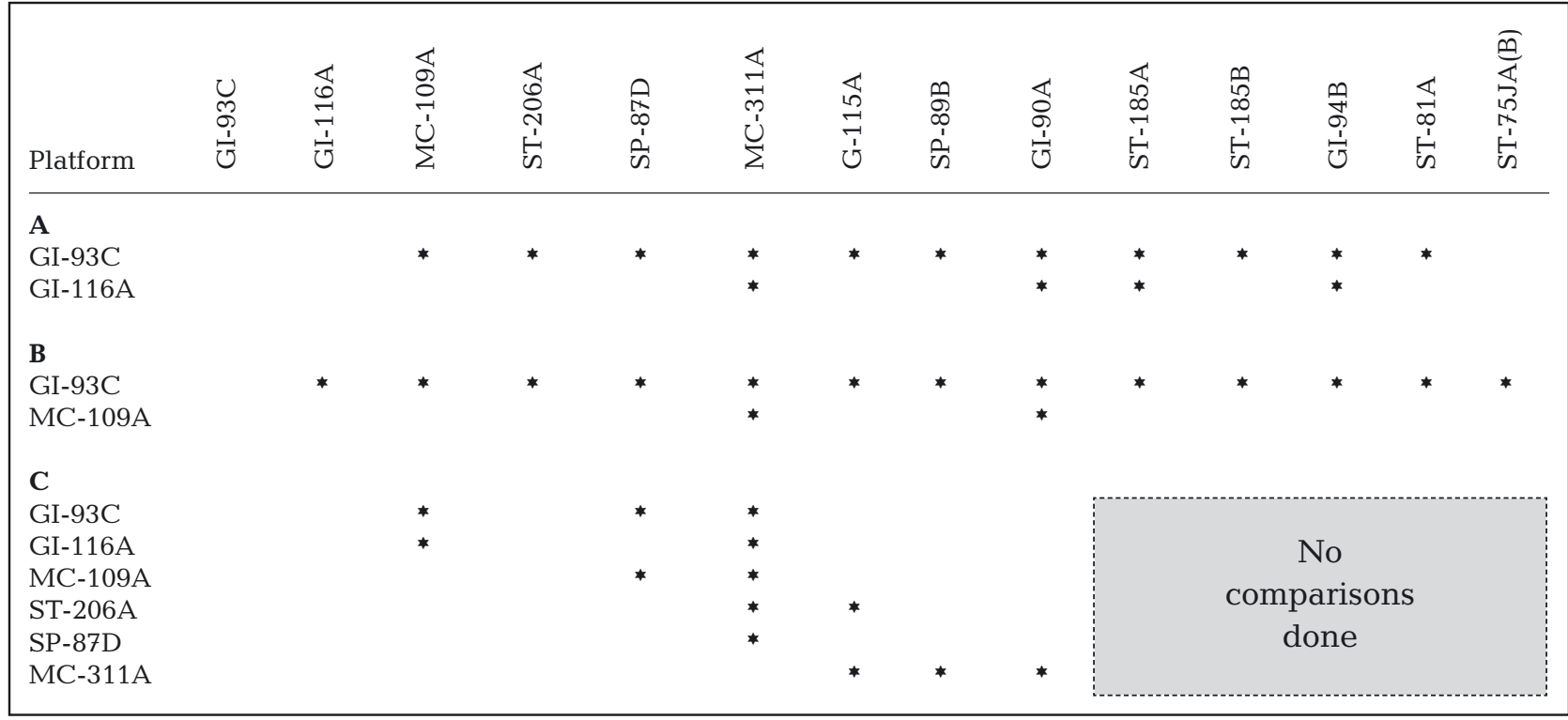

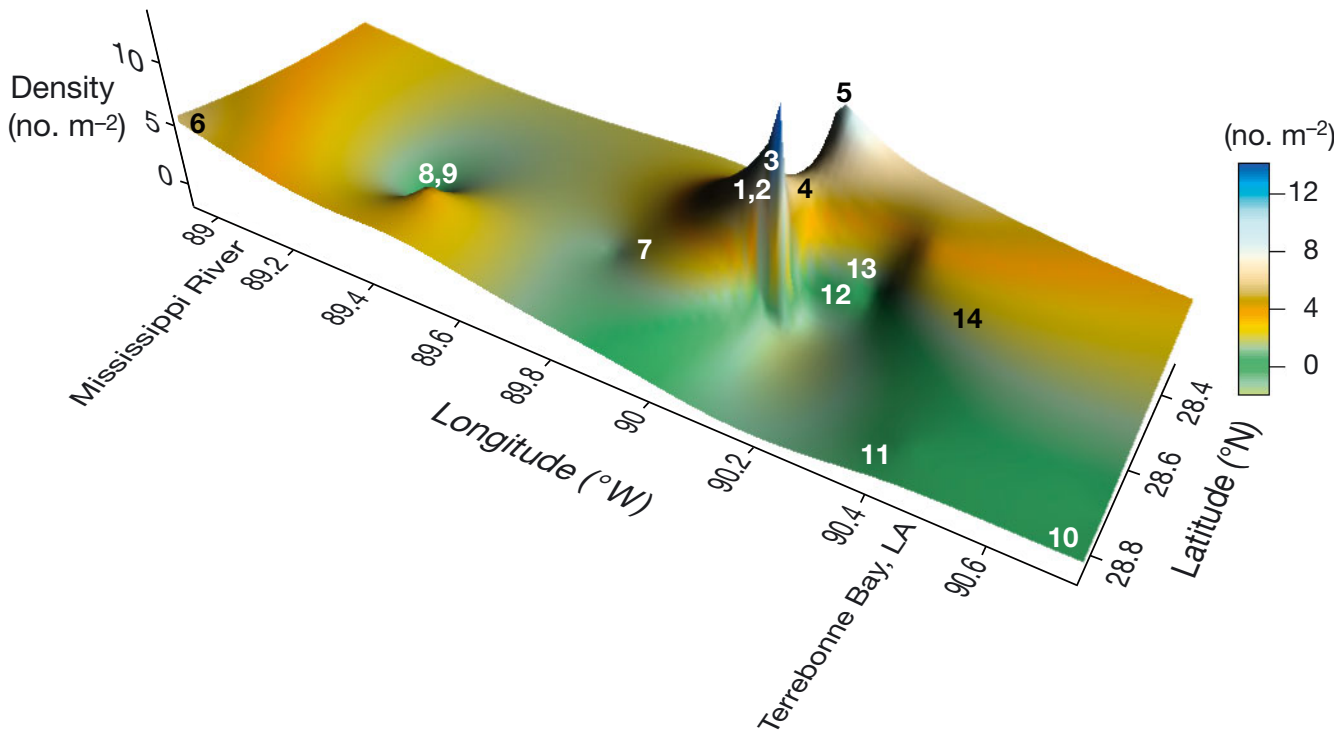

Fig. 3. Geographic distribution of the density of Tubastraea micranthus in the northern GOM, south of the Mississippi River mouth. Note the primary peak (at GI-93C), the secondary peak (at GI$116 \mathrm{~A}$ ) indicating a strong southerly spread, and the dissipation of density radially from these points. Numbers represent study platforms. See Table 1 for platform names

(Fig. 4) and was significantly higher than on all other platforms (see Table 2B for pair-wise inter-platform comparisons). The next largest average T. micranthus colony size was on MC-109A (mean = $198.6 \mathrm{~cm}^{2}, \mathrm{SD}=281.14, \mathrm{n}=47$, range $=1.2$ to $1204 \mathrm{~cm}^{2}$ ). Average colony size on almost all other platforms did not differ significantly from each other (except on GI-115A). In a geographical context, colony size not only peaked at MC-311A but also dropped off evenly from that point in all directions, with no secondary peaks in that region (Fig. 5).
Size-frequency distributions of Tubastraea micranthus revealed that on Platform MC-109A, a large proportion of the colonies $(\sim 60 \%)$ were between 1 and $100 \mathrm{~cm}^{2}$ in area $(\max$. diameter $=\sim 11 \mathrm{~cm}$; Fig. 6). Colony size decreased in frequency rapidly above this small size. This pattern of a logarithmic decrease in the frequency of larger colonies and a heavy representation of very small colonies was mimicked on all other platforms where T. micranthus occurred, particularly GI-93C and GI-116A (Fig. 6). This is similar to the observations made in 


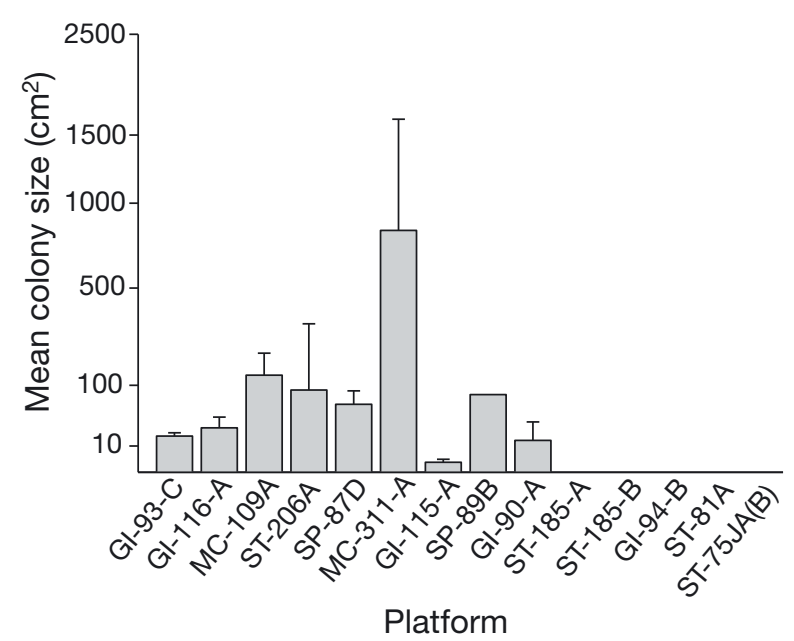

Fig. 4. Mean colony size of Tubastraea micranthus in the northern GOM, south of the Mississippi River mouth. Note that the largest average colony sizes are found on MC-311A, a potential original site of colonization and one which occurs in blue water within the Mississippi Canyon, unlike many of the other sites. Significant difference between colony sizes on different platforms $(\mathrm{p}<0.001,1$-way ANOVA; see Table 2B for detailed comparisons). Data transformed by square root $(Y+0.5)$ for normalization purposes. See Table 1 for sample sizes

Brazil by Lages et al. (2011) and Sampaio et al. (2012). The dimensions of the largest colonies found and the proportion of the population at each site reaching those sizes is shown in the figures. It is not known whether maximum colony size for this species was reached here, for we are not aware of data on maximum colony sizes for $T$. micranthus in its native habitat.

\section{Tubastraea coccinea}

Densities of Tubastraea coccinea were much higher than those of T. micranthus, with the highest densities in this survey reaching $\sim 300$ colonies $\mathrm{m}^{-2}$, 20 -fold higher than that of the new invasive species (Fig. 7). Platform ST-185B exhibited the highest concentrations of $T$. coccinea. GI-116A was similar, and these two were 2 to 3 times higher than on most other platforms (see Table $2 \mathrm{C}$ for pair-wise inter-platform comparisons).

The geographic distribution of Tubastraea coccinea colony density in this region of the northern GOM was similar to that of the recent invader T. micranthus (Fig. 8). The major peaks occurred southwest of the mouth of the Mississippi River, and densities decreased radially in all directions from there.

\section{DISCUSSION}

The pattern reported here for the 14 platforms surveyed, in which the highest densities of Tubastraea micranthus were on Platform GI-93-C, indicates that that platform may have received a major influx of larvae from populations from one or more nearby platforms. On the other hand, it may have been the initial point of colonization, but this is less likely, based on size-frequency information (see below). The geographic distribution of T. micranthus densities throughout the study region also supports the former hypothesis. The secondary peak at GI-116A

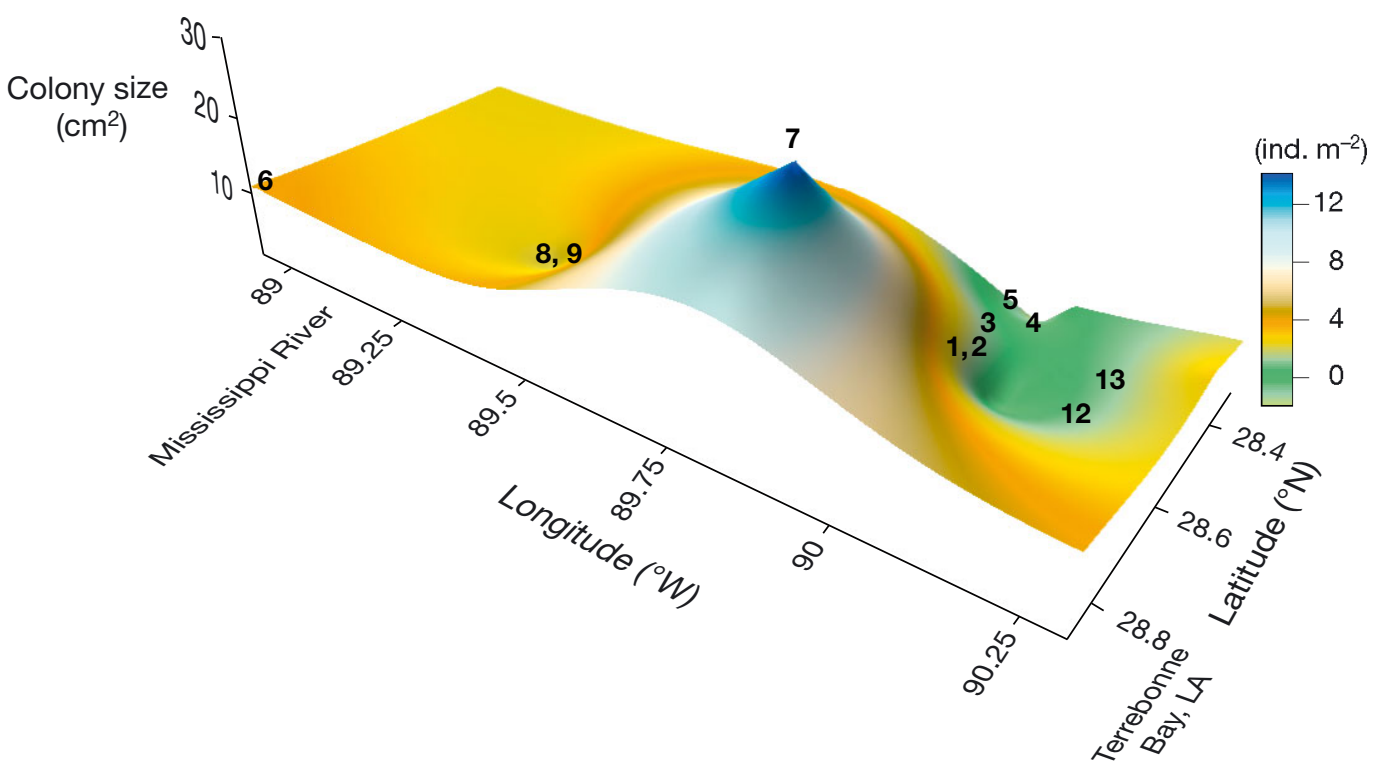

Fig. 5. Geographic distribution of the mean colony size of Tubastraea micranthus in the northern GOM, south of the Mississippi River mouth. Note the primary peak at MC-311A (within the Mississippi Canyon) and how average colony size decreases radially from that point, indicating that this site might possess the best environmental conditions for growth for this species. Numbers represent study platforms. See Table 1 for platform names 

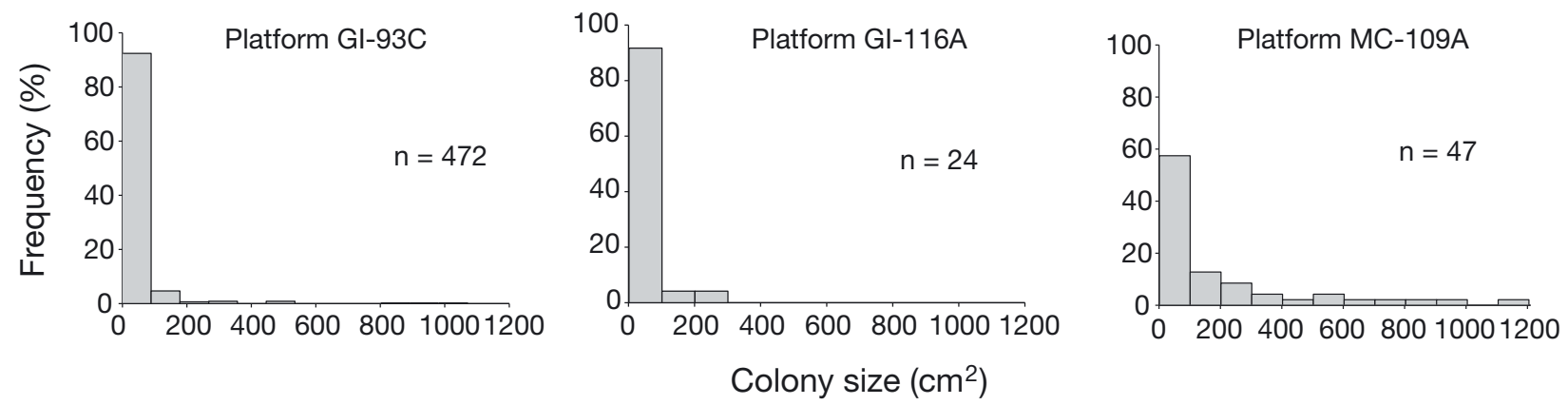

Fig. 6. Size-frequency distribution of colonies of Tubastraea micranthus on 3 platforms in the northern GOM, near the Mississippi River mouth, exemplary of distributions found on all platforms. Note the abundance of smaller-sized colonies, potentially indicating high population growth with low doubling times. Platform GI-93C: mean $=33.5 \mathrm{~cm}^{2}, \mathrm{SD}=94.18, \mathrm{n}=472, \mathrm{~g}_{1}=$ 7.19, $\mathrm{g}_{2}=63.11$. Platform GI-116A: mean $=34.7 \mathrm{~cm}^{2}, \mathrm{SD}=45.60, \mathrm{n}=24, \mathrm{~g}_{1}=2.74, \mathrm{~g}_{2}=8.23$. Platform MC-109A: mean $=$ $198.6 \mathrm{~cm}^{2}, \mathrm{SD}=281.14, \mathrm{n}=47, \mathrm{~g}_{1}=1.92, \mathrm{~g}_{2}=3.36$

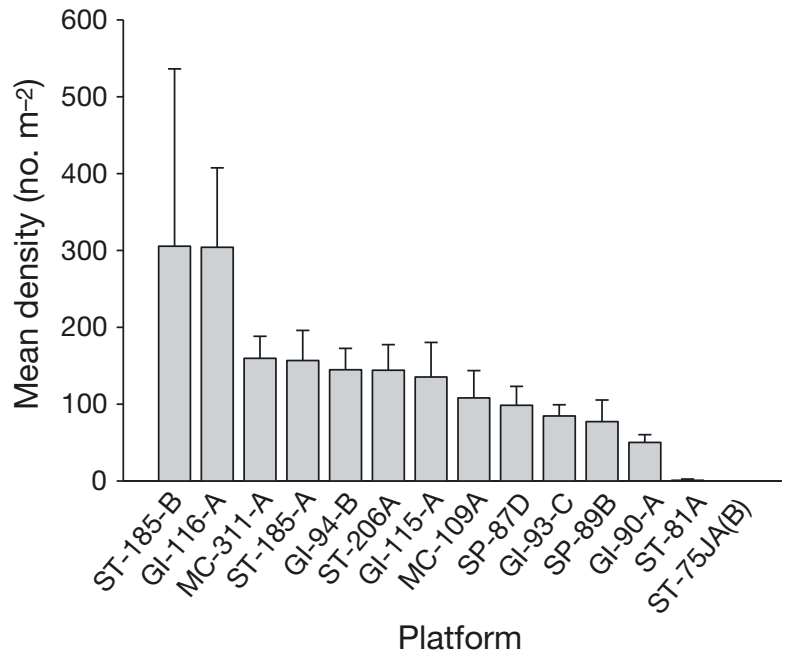

Fig. 7. Density of Tubastraea coccinea in the northern GOM on 14 platforms off the mouth of the Mississippi River. Densities shown in colonies $\mathrm{m}^{-2}$ with $95 \%$ confidence limits. Densities are highly significantly different from each other $(\mathrm{p}<0.001,1$-way ANOVA). Data transformed via squareroot of $(Y+0.5)$ for purposes of normalization (see Sokal \& Rohlf 1981). See Table $2 C$ for details of inter-platform comparisons. See Table 1 for sample sizes

suggests a similar relationship. T. micranthus is known to be able to double its colony density in a single year (Loch et al. 2004).

It has been suggested that size is a better indicator of population dynamics in corals than age (Hughes 1984, Goffredo \& Lasker 2006). Although size has been used often as a target variable in colonial organisms (Grigg 1975), colony age and size data and their impact on calculations of current and future population growth can be confounded (Grigg 1975, Hughes \& Connell 1987, Babcock 1991, ChadwickFurman et al. 2000). Guzner et al. (2007) found that age structure without estimates of recruitment can be misleading due to incomplete data. Bak \& Meesters (1998) suggested that the coefficient of variation, mode, and skewness of a coral population sizefrequency distribution can provide valuable information regarding the population dynamics of a coral population. Done (1988) and Fong \& Glynn (1998) used coral colony size-frequency data to predict coral community recovery times after a major perturbation, such as a crown-of-thorns sea star Acanthaster planci population explosion.

Data regarding the size-frequency distribution of Tubastraea micranthus colonies on these platforms have important implications for the point of initial colonization, niche specificity, and population dynamics of this species. Firstly, average colony size did not peak at GI-93-C it peaked on MC-311A and to some degree on MC-109A, being significantly higher than at all other survey platforms and with colony sizes clearly falling off in all directions from there. However, a further analysis of MC-109A indicated that the size-frequency distribution was similar to those on most of the other platforms, being dominated by very small colonies. It is possible that MC311A could have been the initial site of colonization since it possesses not the most abundant population of $T$. micranthus but the largest colonies in this young set of coral populations.

The currents in this region may be expected to flow from east to west, particularly during the spawning season due to the Loop Current (Sturges \& Blaha 1976, Hamilton et al. 1999). Larvae may also have been carried by a counter-current (Wiseman \& Garvine 1995) to the Western Boundary Current (Vidal Lorandi et al. 1999). This would flow from the east to the north and west and could have carried larvae in 


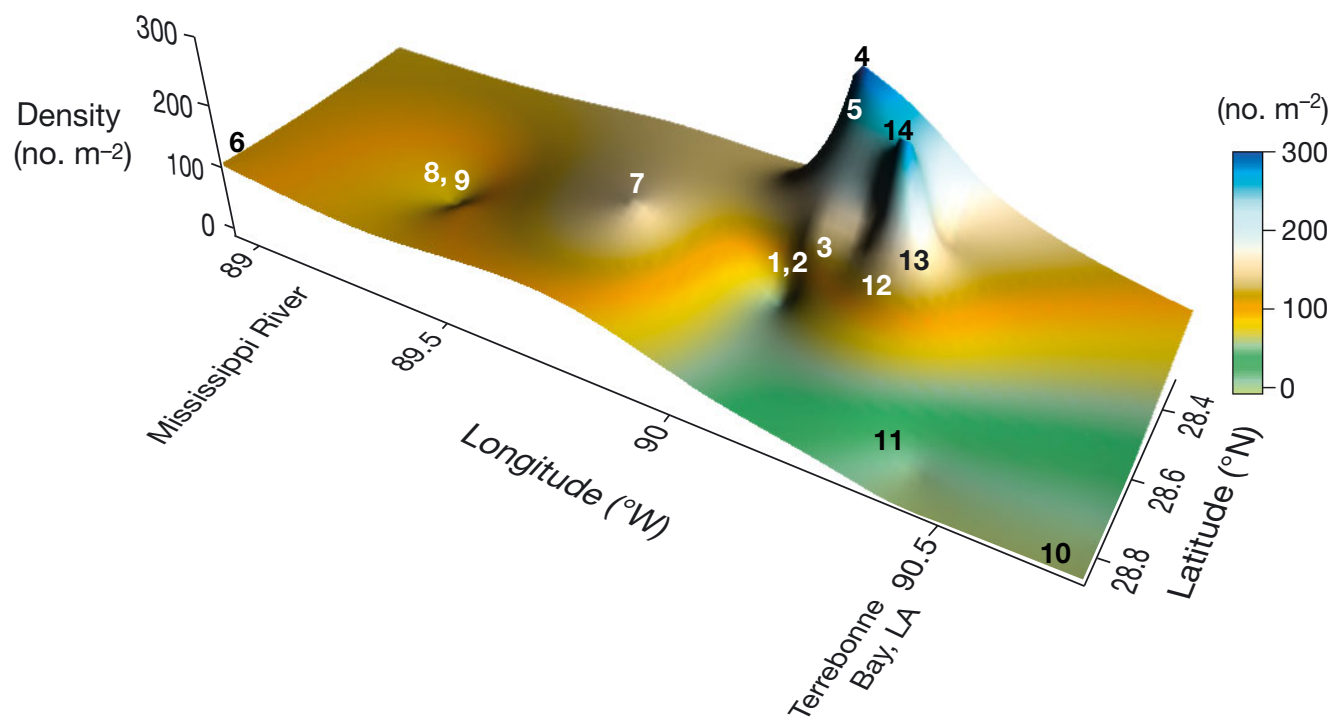

Fig. 8. Geographic distribution of the density of Tubastraea coccinea in the northern GOM, south of the Mississippi River mouth. Note the primary peaks (at ST185B and GI-116A), exhibiting a distribution pattern similar to that of T. micranthus. Also note the dissipation of density radially from these points. Numbers represent study platforms. Platform names given in Table 1

that direction. Another current from the east is that associated with the Tortugas Bank and Pulley Ridge, Florida (Jarrett et al. 2000, Meyers et al. 2001). (See Sturges \& Lugo-Fernandez 2005 for a complete review of currents in the GOM, including this region.) Any of these currents could have influenced larval dispersal and settlement, and they suggest opportunities for future research in this area. In addition, it is known that success of coral recruitment and growth may be regulated by a diverse set of environmental factors, many of which vary in this region.

In all cases, however, we know that the skewness of the size-frequency distributions was high and clearly biased toward the smallest colony sizes. This pattern is similar to that described by McNaughton \& Wolf (1979) of a rapidly expanding population, where most of a population is comprised of pre-reproductive organisms followed by reproductive ones. Such a population would not yet be considered stable. In addition, studies of reproduction and size-structure in red corals have shown that reproductive output increases with size (Tsounis et al. 2006). Because of this, we hypothesize that all of the populations observed, irrespective of average size of the colony, are in a phase of high initial population growth.

The environment of MC-311A is different from that of GI-93-C and may also provide a more suitable environment for growth than the other sites. GI-93-C occurs on the continental shelf in $64 \mathrm{~m}$ depth, and it periodically receives water from the Mississippi River plume as the plume meanders through this region. The river plume is characterized by high turbidity, a high sediment load, high nutrients, and low salinity (Sturges \& Lugo-Fernandez 2005, Rabalais et al. 1996). In contrast, MC-311A occurs beyond the edge of the continental shelf, at the head of the Mississippi Canyon. It is more frequently characterized by blue water (low turbidity, low sediment load, low nutrients - except during upwelling events - and a more stable stenohaline environment; see Rabalais et al. 1996, Weisberg \& He 2003, Green et al. 2006). Thus, we hypothesize that Tubastraea micranthus grows better than $T$. coccinea in a blue-water environment than in a coastal one that is subjected to typical coastal environmental variability.

Highest densities of Tubastraea coccinea were found on ST-185B and GI-116A. Both of these sites have environments similar to GI-93-C and are subjected regularly to water from the Mississippi River plume. This species was also commonly observed on mid-shelf waters subjected to coastal discharge influences in the northern GOM, where hermatypic (reefbuilding) corals were not encountered (Sammarco et al. 2012a). This is another indication that there may be differences in niche specificity and preferred habitat between these 2 congeners. We hypothesize that $T$. coccinea tolerates and perhaps thrives better in coastal or river-influenced waters that are not as well tolerated by $T$. micranthus or by most other tropical reef corals.

This observation raises an interesting point regarding potential impacts of Tubastraea micranthus vs. T. coccinea. T. coccinea invaded the western Atlantic in the 1940s (Cairns 2000, Humann \& DeLoach 2002, Fenner \& Banks 2004). Since that time, it has spread as far south as Brazil (Figueira de Paula \& Creed 2004) and as far north as the Flower Garden Banks (Fenner 1999, 2001, Fenner \& Banks 2004), the Flo- 
rida Keys (Shearer 2008), and platforms in the northern GOM (Sammarco et al. 2012a). Tubastraea spp. in Brazil are showing signs of expansion and disruption of native species (Lages et al. 2011, Sampaio et al. 2012). Populations of this species have nearly monopolized artificial hard-bottom substrata, such as offshore platforms. In no case of which we are aware, however, has this species dominated natural, exposed coral reef environments, despite the fact that it does occur on these natural reefs in the western Atlantic in both shallow and deep environments (Sammarco et al. 2012b, Hickerson et al. 2006).

We hypothesize that the reason for low colony densities on natural reefs is that Tubastraea coccinea may not compete well for space with the natural sessile epibenthic fauna and flora, at least on coral reefs it has colonized in the western Atlantic thus far. It is also possible that predators have been suppressing their populations when they are fully exposed, as has been suggested by Lages et al. (2010). On these reefs, the coral colonies tend to occupy habitats similar to those they occupy in the Indo-Pacific region, habitats that are cryptic. The coral is present in low numbers, associated with other ahermatypic corals. The concern here is that the natural environment for T. micranthus in the Indo-Pacific is on the upper surfaces of reef substratum, fully exposed (Schuhmacher 1984, Muzaki 2011). If and when this species encounters a natural Atlantic coral reef, it is possible that it may be successful at outcompeting naturally occurring sessile epibenthic fauna and flora for space. Its degree of toxicity and palatability to predators, which could potentially control its populations, are currently unknown.

The size-frequency distributions of Tubastraea miranthus suggest that these populations may be in a high growth phase (McNaughton \& Wolf 1979). In the case of Platform MC-109A, almost $60 \%$ of the colonies are between 1 and $100 \mathrm{~cm}^{2}$ in area or $\sim 5 \mathrm{~cm}$ in diameter, while the largest colony was $1200 \mathrm{~cm}^{2}$ or $\sim 40 \mathrm{~cm}$ in diameter. We are unaware of what the maximum size for this species is in its natural environment, but available images indicate that it is on the order of $1 \mathrm{~m}$. In addition, the size-frequency distributions were highly consistent from platform to platform; thus, high population growth may be occurring on all of the newly colonized platforms. It is possible that the similar colony size patterns of all these populations indicate that they have reached a mature, stable size structure, but this is unlikely, given the assumed timing of the introduction. The shape of this single-point size-frequency distribution is similar to that of organisms with a high growth rate and low doubling times (Craig \& Oertel 1966, Kormondy 1969, McNaughton \& Wolf 1979).

Two factors limit our interpretations of population growth. First, they represent only one sampling point in time. Having a temporal data sequence would more easily address some of the hypotheses proposed here. That is, it is not possible to confirm from the data in-hand whether these populations are stable or dynamic. From other studies of expanding populations, however, we assume at this point in time that the populations of Tubastrea micranthos studied here are dynamic. Second, having only density and size-frequency data is in itself limiting. Nonetheless, we offer these explanatory hypotheses for consideration.

The data presented here suggest that Tubastraea micranthus has successfully invaded the northern GOM and may be expanding its populations in this region. Its congener, $T$. coccinea, has already demonstrated a strong capability for geographic range extension. Preliminary data on depth distribution and competitive abilities (Sammarco et al. 2012c, in press $a, b)$ give cause for further concern about the invasion of $T$. micranthus. These data suggest that $T$. micranthus has the ability for extensive geographic expansion in the western Atlantic Ocean if left unchecked. Complete eradication of introduced marine species is possible, but as such can be difficult, and eradication efforts must be swift and complete if they are to be effective (Fitzhugh \& Rouse 1999). In that case, it is possible that the window for action may be closing. If introduced populations are left unchecked for too long, the new species can become well integrated into its target community, creating a new community structure and stable equilibrium, with a new balance of ecological interactions among species (Mooney \& Cleland 2001, Krushelnycky \& Gillespie 2008). In that case, eradication may create more problems than it solves (Bergstrom et al. 2009, Casey 2009). At this point, we stand at a branch in the decision-making road regarding eradication of T. micranthus.

Acknowledgements. We express our deep-felt thanks to the following for their topside assistance in the field: LUMCON-C. Sevin, T. Widgeon, M. Wike; M/V 'Fling' - B. Allen, K. Bush, K. Dies, M. McReynold, B. Oldham, M. Spurgeon, J. Tyler; NASA/US Air Force-D. Perrenod; others M. Gaskill. For their financial support of the project, we extend our thanks to the Bureau of Ocean Energy Management (BOEM), US Department of Interior through the Louisiana State University Coastal Marine Institute (CMI) program, under the direction of L. Rouse and S. Welsh, under grant \#M08AC12865. 


\section{LITERATURE CITED}

Albins MA, Hixon MA (2011) Worst case scenario: potential long-term effects of invasive predatory lionfish (Pterois volitans) on Atlantic and Caribbean coral-reef communities. Env Biol Fish 96:1151-1157

Atchison AD (2005) Offshore oil and gas platforms as stepping stones for expansion of coral communities: A molecular genetic analysis. MSc thesis, Dept Oceanography and Coastal Sciences, Louisiana State University, Baton Rouge, LA

Atchison AD, Sammarco PW, Brazeau DA (2008) Genetic connectivity in corals on the Flower Garden Banks and surrounding oil/gas platforms, Gulf of Mexico. J Exp Mar Biol Ecol 365:1-12

Ayre DJ, Resing JM (1986) Sexual and asexual production of planulae in reef corals. Mar Biol 90:187-190

$>$ Babcock RC (1991) Comparative demography of three species of scleractinian corals using age- and sizedependent classifications. Ecol Monogr 61:225-244

Bak RPM, Meesters EH (1998) Coral population structure: the hidden information of colony size-frequency distributions. Mar Ecol Prog Ser 162:301-306

Bax N, Williamson A, Gonzalez E, Geeves W (2003) Marine alien invasive species: a threat to global diversity. Mar Policy 27:313-323

> Bergstrom DM, Lucieer A, Kiefer K, Wasley J, Belbin L, Pedersen TK, Shown SL (2009) Indirect effects of invasive species removal devastate World Heritage Island. J Appl Ecol 46:73-81

Cairns SD (2000) Revision of the shallow-water azooxanthellate Scleractinia of the western Atlantic. Stud Nat Hist Caribb Reg 75:1-240

Cairns SD (2001) A generic revision and phylogenetic analysis of the Dendrophylliidae (Cnidaria: Scleractinia). Smithson Contrib Zool 615:1-75

Cairns SD, Zibrowius H (1997) Cnidaria Anthozoa: azooxanthellate Scleractinia from the Philippine and Indonesian regions. Mem Mus Nat His Nat (Fr) 172:27-243

Casey M (2009) Species eradication backfires big time. CBS News, 13 Jan 2009, www.cbsnews.com/stories/2009/01/ 13/tech/main4719190.shtml

> Chadwick-Furman NE, Goffredo S, Loya Y (2000) Growth and population dynamic model of the reef coral Fungia granulosa Klunzinger 1879 at Eilat, northern Red Sea. J Exp Mar Biol Ecol 249:199-218

Chapman AS (1999) From introduced species to invader: What determines variation in the success of Codium fragile ssp. tomentosoides (Chlorophyta) in the North Atlantic Ocean? Helgol Meeresunters 52:277-289

- Chapman D, Ranelletti M, Kaushik S (2006) Invasive marine algae: an ecological perspective. Bot Rev 72:153-178

Chesapeake Bay Commission (1995) The introduction of non-indigenous species to the Chesapeake Bay via ballast water. Strategies to decrease the risks of future introductions through ballast water management. Chesapeake Bay Comm, Annapolis, MD

Christmas J, Eades R, Cincotta D and others (2001) History, management, and status of introduced fishes in the Chesapeake Bay basin. In: Therres GD (ed) Proceedings of Conservation of Biological Diversity: a Key to the Restoration of the Chesapeake Bay Ecosystem and Beyond, May 10-13, 1998. Maryland Dept. of Natural Resources, Annapolis, MD, p 97-116

Craig GY, Oertel G (1966) Deterministic models of living and fossil populations of animals. Q J Geol Soc 122: 315-354

Done TJ (1988) Simulation of recovery of pre-disturbance size structure in populations of Porites spp. damaged by the crown of thorns starfish Acanthaster planci. Mar Biol 100:51-61

Elton CS (2000) The ecology of invasions by animals and plants. University of Chicago Press, Chicago

Fenner D (1999) New observations on the stony coral (Scleractinia, Milleporidae, and Stylasteridae) species of Belize (Central America) and Cozumel (Mexico). Bull Mar Sci 64:143-154

Fenner D (2001) Biogeography of three Caribbean corals (Scleractinia) and the invasion of Tubastraea coccinea into the Gulf of Mexico. Bull Mar Sci 69:1175-1189

Fenner D, Banks K (2004) Orange cup coral Tubastraea coccinea invades Florida and the Flower Garden Banks, northwestern Gulf of Mexico. Coral Reefs 23:505-507

Figueira de Paula A, Creed JC (2004) Two species of the coral Tubastraea (Cnidaria, Scleractinia) in Brazil: a case of accidental introduction. Bull Mar Sci 74:175-183

Fitzhugh K, Rouse GW (1999) A remarkable new genus and species of fan worm (Polychaeta: Sabellidae: Sabellinae) associated with marine gastropods. Invertebr Biol 118: 357-390

Fong P, Glynn PW (1998) A dynamic size-structured population model: Does disturbance control size structure of a population of the massive coral Gardineroseris planulata in the eastern Pacific? Mar Biol 130:663-674

Glynn PW, Colley SB, Mate JL, Cortes J and others (2008a) Reproductive ecology of the azooxanthellate coral Tubastraea coccinea in the equatorial eastern Pacific: Part V. Dendrophylliidae. Mar Biol 153:529-544

Glynn PW, Colley SB, Mate JL, Cortes J and others (2008b) Reproductive ecology of the azooxanthellate coral Tubastraea coccinea in the equatorial eastern Pacific: Part V. Dendrophylliidae (erratum). Mar Biol 154:199

> Goffredo S, Lasker HR (2006) Modular growth of a gorgonian coral can generate predictable patterns of colony growth. J Exp Mar Biol Ecol 336:221-229

Golden Software (2002) Surfer 8: user's guide. Golden Software, Golden, CO

Graham WM, Bayha KM (2008) Assessing oil and gas platforms for settlement of jellyfish polyps in the northern Gulf of Mexico. Proc 24 ${ }^{\text {th }}$ Gulf of Mexico Information Transfer Meeting, US Dept Interior, Minerals Management Service, New Orleans, LA, OCS Report No. 2008012, p 348

Graham WM, Martin DL, Felder DL, Asper VL, Perry HM (2003) Ecological and economic implications of a tropical jellyfish invader in the Gulf of Mexico. Biol Invasions 5: 53-69

Green RE, Bianchi TS, Dagg MJ, Walker ND, Breed GA (2006) An organic carbon budget for the Mississippi River turbidity plume and plume contributions to air-sea $\mathrm{CO}_{2}$ fluxes and bottom water hypoxia. Estuaries Coasts 29:579-597

Griffiths RW (1991) Spatial distribution and dispersal mechanisms of zebra mussels in the Great Lakes basin. J Shellfish Res 10:1-248

> Grigg RW (1975) Age structure of a longevous coral: a relative index of habitat suitability and stability. Am Nat 109: 647-657

Guzner B, Novoplansky A, Chadwick NE (2007) Population dynamics of the reef-building coral Acropora hembrichii 
as an indicator of reef condition. Mar Ecol Prog Ser 333: $143-150$

- Halford A, Cheal AJ, Ryan D, Williams DMcB (2004) Resilience to large-scale disturbance in coral and fish assemblages on the Great Barrier Reef. Ecology 85:1892-1905

Hamilton P, Fargion GS, Biggs DC (1999) Loop current eddy paths in the western Gulf of Mexico. J Phys Oceanogr 29: 1180-1207

Hamner RM, Freshwater D, Whitfield P (2007) Mitochondrial cytochrome b analysis reveals two invasive lionfish species with strong founder effects in the western Atlantic. J Fish Biol 71:214-222

Hebbinghaus R (2001) Larval development, hatching and care of the stony coral (Tubastraea cf. coccinea) in a closed system. Bull Inst Oceanogr Monaco 20:355-358

Hickerson EL, Schmahl GP, Weaver DC (2006) Patterns of deep coral communities on reefs and banks in the northwestern Gulf of Mexico. Eos Trans AGU 87:36

Hicks DW, Tunnell JW Jr (1993) Invasion of the south Texas coast by the edible brown mussel Perna perna (Linnaeus, 1758). Veliger 63:92-94

> Hindar K, Fleming IA, McGinnity P, Diserud O (2006) Genetic and ecological effects of salmon farming on wild salmon: modeling from experimental results. ICES J Mar Sci 63:1234-1247

Hughes TP (1984) Population dynamics based on individual size rather than age: a general model with a reef coral example. Am Nat 123:778-795

Hughes TP, Connell JH (1987) Population dynamics based on size or age? A reef-coral analysis. Am Nat 129:818-829

Humann P, Deloach N (2002) Reef coral identification: Florida, Caribbean, Bahamas, including marine plants. New World Publications, Jacksonville, FL

ICES (2002) Report of the ICES/IOC/IMO study group on ballast and other ship vectors - Gothenburg, Sweden, 18-19 March 2002. ICES CM, ICES, Copenhagen

Jarrett BD, Hine AC, Neumann AC, Narr D, Locker S, Malinson D, Jaap W (2000) Deep biostromes at Pulley Ridge: Southwest Florida carbonate platform. In: Hallock P, French L (eds) Diving for science in the 12st century. Am Acad Underwater Sci, Nahant, MA, p 14

> Johnson LE, Carlton JT (1996) Post-establishment spread in large-scale invasions: dispersal mechanisms of the zebra mussel Dreissena polymorpha. Ecology 77:1686-1690

Kerr SJ, Brousseau CS, Muschett M (2005) Invasive aquatic species in Ontario: a review and analysis of potential pathways for introduction. Fisheries (Bethesda, Md) 30: 21-30

Kormondy EJ (1969) Concepts of ecology. Prentice-Hall, Englewood Cliffs, NJ

- Krushelnycky PD, Gillespie RG (2008) Compositional and functional stability of arthropod communities in the face of ant invasions. Ecol Appl 18:1547-1562

Lages BG, Fleury BG, Pinto AC, Creed JC (2010) Chemical defenses against generalist fish predators and fouling organisms in two invasive ahermatypic corals in the genus Tubastraea. Mar Ecol 31:473-482 doi:10.1111/j. 1439-0485.2010.00376.x

> Lages BG, Fleury BG, Menegola C, Creed JC (2011) Change in tropical rocky shore communities due to an alien coral invasion. Mar Ecol Prog Ser 438:85-96

LaJeunesse TC, Lee S, Bush S, Bruno JF (2005) Persistence of non-Caribbean algal symbionts in Indo-Pacific mushroom corals released to Jamaica 35 years ago. Coral Reefs 24:157-159
Loch K, Loch W, Schuhmacher H, See WR (2004) Coral recruitment and regeneration on a Maldivian reef four years after the coral bleaching event of 1998. Part 2: 2001-2002. Mar Ecol 25:145-154

McNaughton SJ, Wolf LL (1979) General ecology. Holt, Rinehart, and Winston, New York, NY

> Meyers SD, Siegel EM, Weisberg RH (2001) Observations of currents on the West Florida shelf break. Geophys Res Lett 28:2037-2040, doi:10.1029/2000GL012249

Minchin D, Gollasch S (2003) Fouling and ships' hulls: how changing circumstances and spawning events may result in the spread of exotic species. Biofouling 19:111-122

Mooney HA, Cleland EE (2001) The evolutionary impact of invasive species. Proc Natl Acad Sci USA 98:5446-5451

Muzaki F (2011) Tubastraea micranthus-Karimunjawa 1 (image). www.fobi.web.id/fbi/updates?g2_albumId= 17383\&g2_itemId=53498 (last viewed 23 Sept 2013)

Osman R, Shirley T (eds) (2007) The Gulf of Mexico and Caribbean marine invasive species workshop: proceedings and final report. Harte Res Inst, Texas A\&M Univ, Corpus Christi, TX

Pagad S (2007) Tubastraea coccinea (corail). Global Invasive Species Database, Invasive Species Specialist Group, IUCN Species Survival Commission. Www.issg.org/ database/species/ecology.asp? si=1096\&fr=1\&sts=\&lang= FR

Pederson J (2000) Marine bioinvasions: proceedings of the first national conference. Proc $1^{\text {st }}$ Nat Conf Marine Bioinvasions, 24-27 Jan 2000, Cambridge, MA

Perry HM, Graham M (2000) The spotted jellyfish: alien invader. Report to NOAA Mississippi-Alabama Sea Grant, Hattiesburg, MS

> Rabalais NN, Turner RE, Dortch Q, Wiseman WJ Jr, Sen Gupta BK (1996) Nutrient changes in the Mississippi River and system responses on the adjacent continental shelf. Estuaries 19:386-407

Roberts PD, Pullin AS (2008) The effectiveness of management interventions for the control of Spartina species: A systematic review and meta-analysis. Aquat Conserv 18:592-618

Rohlf FJ, Slice DE (1996) BIOMstat for Windows: statistical software for biologists, Vers 3.2. Exeter Software, Setauket, NY

Sammarco PW, Atchison A, Boland GS (2004) Expansion of coral communities within the northern Gulf of Mexico via offshore oil and gas platforms. Mar Ecol Prog Ser 280: 129-143

Sammarco PW, Atchison AD, Brazeau DA, Boland GS, Lirette A (2007a) Expansion of scleractinian corals across the N. Gulf of Mexico: a bird's eye view of large-scale patterns and genetic affinities. Proc Austral Mar Sci Assoc, Melbourne (Abstract)

Sammarco PW, Brazeau DA, Atchison AD, Boland GS, Lirette A (2007b) Coral distribution, abundance, and genetic affinities on oil/gas platforms in the N. Gulf of Mexico: a preliminary look at the Big Picture. Proc US Dept. Interior Minerals Management Service Information Transfer Meeting Jan 2007, New Orleans, LA

Sammarco PW, Atchison AD, Brazeau DA, Boland GS, Hartley SB, Lirette A (2008) Distribution, abundance, and genetics of corals throughout the N. Gulf of Mexico: the world's largest coral settlement experiment. Proc 11th Int Coral Reef Symp, Fort Lauderdale, FL, July 2008, Abstract

> Sammarco PW, Porter SA, Cairns SD (2010) A new coral spe- 
cies introduced into the Atlantic Ocean-Tubastraea micranthus (Ehrenberg, 1834) (Cnidaria, Anthozoa, Scleractinia): An invasive threat? Aquat Invasions 5: 131-140

Sammarco PW, Atchison AD, Boland GS, Sinclair J, Lirette A (2012a) Geographic expansion of hermatypic and ahermatypic corals in the Gulf of Mexico, and implications for dispersal and recruitment. J Exp Mar Biol Ecol 436-437: 36-49

Sammarco PW, Brazeau DA, Sinclair J (2012b) Genetic connectivity in scleractinian corals across the northern Gulf of Mexico: oil/gas platforms, and relationship to the Flower Garden Banks. PLoS ONE 7:e30144

Sammarco PW, Porter SA, Genazzio M, Sinclair J (2012c) Successful invasion of Tubastraea micranthus into the western Atlantic. Abstracts of Int Coral Reef Symp, Cairns, Qld, Australia, July 2012

Sammarco PW, Lirette A, Tung YF, Boland GS, Genazzio M, Sinclair J (in press a) Coral communities on artificial reefs in the Gulf of Mexico: standing vs. toppled oil platforms. ICES J Mar Sci

Sammarco PW, Porter SA, Sinclair J, Genazzio M (in press b) Depth distribution of a new invasive coral (Gulf of Mexico)-Tubastraea micranthus, comparisons with $T$. coccinea, and implications for control. Management of Biological Invasions

Sampaio CIS, Miranda RJ, Maia-Nogueira RM, Nunes JACC (2012) New occurrences of the non-indigenous orange cup corals Tubastraea coccinea and T. tagusensis (Scleractinia: Dendrophylliidae) in southwestern Atlantic. Check List 8:528-530 www.checklist.org.br/getpdf? NGD202-11

Sapota MR (2004) The round goby (Neogobius melanostomus) in the Gulf of Gdansk - a species introduction into the Baltic Sea. Hydrobiologia 514:219-224

Schmahl GP (2003) Biodiversity associated with topographic features in the northwestern Gulf of Mexico. Proc US Dept. Interior, Minerals Management Service Information Transfer Meeting, Gulf of Mexico, OCS Region, Kenner, LA

Schmahl GP, Hickerson EL (2006) Ecosystem approaches to the identification and characterization of a network of reefs and banks in the northwestern Gulf of Mexico. Eos Trans Am Geophys Union 87 (suppl) (abstract)

Schuhmacher H (1984) Reef-building properties of Tubastraea micranthus (Scleractinia, Dendrophylliidae), a coral without zooxanthellae. Mar Ecol Prog Ser 20: 93-99

Shearer TL (2008) Range expansion of an introduced coral: investigating the source and ecological impact of the invasion. In: 2008 Ocean Science Meeting: from the watershed to the Global Ocean, March 2-7, 2008, Orlando, FL, Meeting Abstracts. ASLO, AGU, The Oceanography Society, Orlando, FL, p 368 (abstract)

Editorial responsibility: Richard Osman, Edgewater, Maryland, USA
Sokal RR, Rohlf FJ (1981) Biometry. Freeman, San Francisco, CA

> Sturges W, Blaha JP (1976) A western boundary current in the Gulf of Mexico. Science 192:367-369

Sturges W, Lugo-Fernandez A (2005) Circulation in the Gulf of Mexico: observations and models. Monogr No 161, Am Geophys Union, Washington, DC

Trowbridge CD (1998) Ecology of the green macroalga Codium fragile (Suringar) Hariot 1889: invasive and noninvasive subspecies. Oceanogr Mar Biol Annu Rev 36: $1-64$

Tsounis G, Rossi S, Aranguren M, Gili JM, Arntz W (2006) Effects of variability and colony size on the reproductive output and gonadal development cycle of the Mediterranean red coral (Corallium rubrum L.). Mar Biol 148: 513-527

Vidal Lorandi FV, Vidal Lorandi VMV, Rodriguez Espinoza PF, Sambrano Salgado L, Portilla Casilla J, Rendon Villalobos JR, de la Cruz BJ (1999) Gulf of Mexico circulation. Rev Soc Mex Hist Nat 49:1-15

Weidema IR (ed) (2000) Introduced species in the Nordic countries. Nordic Council of Ministers, Copenhagen. Nord 2000:13

Weisberg RH, He R (2003) Local and deep-ocean forcing contributions to anomalous water properties on the west Florida shelf. J Geophys Res 108, 3184, doi:10.1029/ 2002JC001407

> Whitfield PE, Gardner T, Vives SP, Gilligann MR, Courtenay WR Jr, Ray GC, Hare JA (2002) Biological invasion of the Indo-Pacific lionfish Pterois volitans along the Atlantic coast of North America. Mar Ecol Prog Ser 235:289-297

- Williams DMcB (1982) Patterns in the distribution of fish communities in the central Great Barrier Reef. Coral Reefs 1:35-43

> Williams SL (2007) Introduced species in seagrass ecosystems: status and concerns. J Exp Mar Biol Ecol 350: 89-110

> Williams SL, Smith JE (2007) A global review of the distribution, taxonomy, and impacts of introduced seaweeds. Annu Rev Ecol Evol Syst 38:327-359

Wiseman WJ, Garvine RW (1995) Plumes and coastal currents near large river mouths. Estuaries 18:509-517

Womersley HBS (ed) (2003) The marine benthic flora of southern Australia. Part IIID: Ceramiales-Delesseriaceae, Sarcomeniaceae, Rhodomelaceae. Australian Biological Resources Study, ACT, Flora of Australia Supplementary Series No. 18, Canberra

> Wonham MJ, Carlton JT, Ruiz GM, Smith LD (2000) Fish and ships: relating dispersal frequency to success in biological invasions. Mar Biol 136:1111-1121

Zenetos A, Cinar ME, Pancucci-Papadopoulou MA, Harmelin JG and others (2005) Annotated list of marine alien species in the Mediterranean with records of the worst invasive species. Mediterr Mar Sci 6:63-118

Submitted: July 23, 2013; Accepted: September 26, 2013

Proofs received from author(s): December 11, 2013 